\title{
Letter from the Editor-in-Chief: Lifting the veil on how institutions matter in IB research
}

\section{Lorraine Eden}

Journal of International Business Studies (2010) 41, 175- 177.

doi: $10.1057 / j i b s .2009 .92$
This issue of JIBS contains a bounty of riches: a Letter from the Editors, eight articles, and two research notes. Two of the articles were submitted under the previous editorial team, but all were completed under the current team.

The issue opens with a Letter from the Editors, "Common method variance in international business research" by Chang, van Witteloostuijn and Eden, a response to the high number of JIBS submissions that appear to suffer from common method variance (CMV). When data sets are constructed solely from self-report questionnaires completed at the same time by the same participants, CMV may be a concern, particularly when the dependent and key independent variables are perceptual and are both drawn from the same survey. CMV can create false internal consistencies that lead to Type I and II errors. In this Letter, the editors explain $\mathrm{CMV}$ and the current state of best practices for handling CMV in international business research.

Several of the articles in JIBS 41.2 cluster around the theme of institutions and international business, which I explore briefly below.

\section{LIFTING THE VEIL ON HOW INSTITUTIONS MATTER}

The fundamental idea behind institutional theory is that institutions matter; they create the "rules of the game" within which actors engage in the economic activities of production, distribution, and exchange (North, 1990). Exactly how institutions matter is less clear. A Special Issue of JIBS (39.4) has been important in "lifting the veil" of our ignorance about how institutions matter. In their Introduction, the guest editors Henisz and Swaminathan (2008: 539) argued that future researchers on institutions and IB should focus on three points:

(1) The institutional environment is not a parameter but a rich constellation of interdependent structures and systems within a country, across dyadic pairs of countries and at the level of the international state system.

(2) Firms' responses to (unexpected) variation in the institutional environment of an investment capture a significant share of senior managers' time and are a key determinant of success and failure.

(3) Firms' responses and their performance implications to a given institutional construct will vary according to multiple criteria including aspects of a firm's prior experience in its home country institutional environment as well as those of other countries in which it has operated. 
We can see each of these three points now being addressed by the authors in JIBS 41.2. Let me start with the "rich constellation" of national innovation systems and firm responses in the form of inward foreign direct investment (IFDI). Guler and Guillén, in "Institutions and the internationalization of US venture capital firms," analyze the role played by host-country institutions in attracting IFDI by US venture capital firms. The authors find that strong national innovation systems, especially legal systems, are particularly important locational attractions. In addition (building on Henisz and Swaminathan's third point), as venture capitalists accumulate more international experience, they are better able to overcome institutional constraints.

Differences in institutions and impacts on firm behavior are also the subject of Boulton, Smart, and Zutter's article, "IPO underpricing and international corporate governance." The authors argue that the impacts of strong investor protection are not always positive: international initial public offering (IPO) issuers are more likely to under price in countries where investor protection is strong. This surprising result (which runs somewhat contrary to Guler and Guillén) is caused by corporate insiders needing outside capital (hence, the IPO) but wanting to also maintain control over the firm. Since strong regulatory institutions give more power to outside investors, one way to maintain control post-IPO is to encourage diffusion of ownership among the outside investors. By underpricing the IPO, the insiders can generate excess demand, diffusing outside ownership and leaving more control to the insiders.

Much IB research has focused on announcements of various forms of cross-border alliances. We know much less about what happens post-announcement. In "Cross-border acquisition abandonment and completion: The effect of institutional differences and organizational learning in the international business service industry, 1981-2001," Dikova, Rao Sahib, and van Witteloostuijn explore what happens after an announced acquisition. Do the firms carry out the acquisition or abandon it, and if abandoned, why? Using the concept of institutional differences, the authors argue that formal and informal (cultural) institutional differences are potential deal-breakers. Firms' experience with international acquisitions, on the other hand, increases the likelihood of completion but only in institutionally less distant countries (linking back to Henisz and Swaminathan's third point).
Institutions not only affect firm behavior but also competitive performance - as measured by exports - according to the next two articles in this issue, building on Henisz and Swaminathan's second point. Schneider, Schulze-Bentrop, and Paunescu, in "Mapping the institutional capital of high-tech firms: A fuzzy-set analysis of capitalist variety and export performance," use the varietiesof-capitalism approach to explore competitive advantage in high-tech industries. The authors compare liberal market economies (LMEs) with coordinated market economies (CMEs), using a qualitative methodology (fsQCA) that codifies necessary and sufficient causal mechanisms. The authors find that LMEs have a comparative advantage relative to CMEs in high-tech industries, as measured by export performance. In addition, through cross-border M\&As that generate knowledge flows, multinational enterprises can arbitrage differences in institutions across countries.

The second paper linking institutions to export performance is "Institutions, size and age in transition economies: Implications for export growth," by Shinkle and Kriauciunas. The authors explore the linkages between firm size and age, export growth and institutions in transition economies. The authors find that size and age have positive diminishing relationships with export growth in transitional economies, but they have U-shaped relationships in less advanced transitional economies.

Building on Henisz and Swaminathan's call for more work at the managerial level, two papers explore relational ties as a strategic response by senior managers to the challenges caused by institutional upheavals in liberalizing economies. Danis, Chiaburu, and Lyles, in "The impact of managerial networking intensity and market-based strategies on firm growth during institutional upheaval: A study of small and medium-sized enterprises in a transition economy," explore the competitive strategies of small- and medium-sized enterprises (SMEs) in Hungary over the 1990-2002 period. The authors argue that SME managers employ networking and market-based strategies as coping mechanisms, and that managerial networking intensity should decline and market-based strategies rise as the economy moves through a transition. Contrary to expectations, market-based strategies were not associated with firm growth either early or late in the transition.

The second article on relational ties, "Network composition, collaborative ties, and upgrading in 
emerging-market firms: Lessons from the Argentine autoparts sector" by McDermott and Corredoira, examines networking relationships in the Argentine autoparts sector. The authors find that upper tier suppliers benefit more than lower tier suppliers, in terms of upgrading, from both professional and social networking ties with foreign assemblers.

\section{OTHER HIGHLIGHTS OF JIBS 41.2}

The article by Malhotra and Hinings, "An organizational model for understanding internationalization processes," argues that the heterogeneity that IB researchers observe in firms' internationalization paths is partly due to the heterogeneity among firms, that is, different types of organizations will internationalize differently. The authors compare three organizational types: mass production, disaggregated production, and projectbased organizations. Each type appears to respond

\section{REFERENCES}

Henisz, W. J., \& Swaminathan, A. 2008. Institutions and international business: Introduction to the Special Issue. Journal of International Business Studies, 39(4): 537-539. differently to critical steps along the internationalization path in terms of entry focus, degree of presence, and physical presence in the foreign market. The authors also link their theoretical models to the offshoring literature.

Two research notes conclude the issue. "The multinational enterprise as a source of international knowledge flows: Direct evidence from Italy" by Driffield, Love, and Menghinello examines technology transfers from MNE parents to their Italian subsidiaries, followed by knowledge spillovers from the subsidiaries to local Italian firms. "Assessing the cross-national invariance of formative measures: Guidelines for international business researchers" by Diamantopoulos and Papadopoulos offers guidelines for assessing (in)equivalence when the focal construct is measured with formative indicators. Their methodology is illustrated with data on consumer perceptions of product-country images.

North, D. C. 1990. Institutions, institutional change and economic performance. Cambridge, MA: Harvard University Press. 